\title{
Maternal protein reserves and their influence on lactational performance in rats 3 . The effects of dietary protein restriction and stage of lactation on milk composition
}

\author{
BY A. P. PINE AND N. S. JESSOP* \\ Institute of Ecology and Resource Management, University of Edinburgh, West Mains Road, \\ Edinburgh EH9 $3 J G$ \\ AND J. D. OLDHAM \\ Genetics and Behavioural Sciences Department, Scottish Agricultural College, West Mains Road, \\ Edinburgh EH9 3JG
}

(Received 3 March 1993 - Revised 9 March 1994-Accepted 12 April 1994)

\begin{abstract}
The effects of severe protein restriction following parturition on the changes in rat milk composition during lactation were investigated using multiparous female Sprague-Dawley rats caged individually following mating and offered a high-protein diet $(\mathrm{H} ; 215 \mathrm{~g}$ crude protein $(\mathrm{N} \times 6.25 ; \mathrm{CP}) / \mathrm{kg}$ dry matter (DM)) ad lib. until parturition. Following parturition, half the females continued to receive diet $\mathrm{H}$, whilst the remainder were offered a diet low in protein $(\mathrm{L} ; 90 \mathrm{~g} \mathrm{CP} / \mathrm{kg} \mathrm{DM}) \mathrm{ad} l i b$. On days $2,4,8$ and 12 of lactation groups of females from both dietary treatments were used to provide a milk sample. Milk samples were analysed for their lactose (enzymically), protein (binding to Coomassie blue), lipid (gravimetrically) and mineral (spectrophotometrically) contents. The milk lactose concentration of group $\mathrm{H}$ increased with stage of lactation $\left(r^{2} 0.85, P<0.001\right)$. Such an increase was prevented by diet $L$, and from day 8 of lactation the milk lactose of group $L$ was lower $(P<0.05)$ than in group $H$. Group H milk protein concentration did not change during lactation and averaged $90.7 \mathrm{mg} / \mathrm{g}$. Dietary protein restriction reduced the milk protein concentration of group $L$ so that on days 2,4 and 12 of lactation it was lower $(P<0.05)$ than that of group $H$. On day 8 of lactation the milk protein concentration of group $L$ had increased $(P<0.05)$ and was comparable with that of group $H$. For group $H$, milk lipid averaged $166.8 \mathrm{mg} / \mathrm{g}$ and was generally unchanged during lactation. Diet $\mathrm{L}$ increased $(P<0.01)$ the milk lipid concentration (205.5 mg/g) compared with diet $H$ and this was also significant on days 4 and 8 of lactation $(P<0.05)$. Group $L$ milk lipid concentration also increased between days 4 and 8 of lactation $(P<0.05)$. Milk Na concentration declined during lactation in both dietary groups $(P<0.01)$ but was unaffected by dietary treatment. Both milk $C a$ and $P$ concentrations increased $(P<0.01)$ during lactation in both dietary groups, whilst protein restriction also increased the $\mathbf{C a}$ and $\mathbf{P}$ concentrations $(P<0.05)$. Milk $K$ and $M g$ concentrations were unaffected by dietary treatment or stage of lactation. This significant alteration in the milk composition of severely protein-restricted dams, while possibly favouring the disposal of greater quantities of energy-yielding nutrients, suggests that equations developed for the estimation of milk production in rats cannot be used under such conditions.
\end{abstract}

Lactation: Milk composition: Feed intake: Dietary protein: Rat

Despite the fact that the laboratory rat has been used extensively as a model in nutritional and biochemical studies of lactation, and that numerous experiments have provided information on rat milk composition and the changes associated with lactation, the

* For reprints. 
conditions that influence such changes during lactation are still not clear. The majority of these studies have investigated either the changes in milk composition associated with stage of lactation and parity (Luckey et al. 1954; Chalk \& Bailey, 1979; Keen et al. 1981; Nicholas et al. 1981) or the effects of dietary protein restriction on milk composition at one sample point in lactation. Monitored in this way (single point sampling), protein restriction throughout both gestation and lactation (Sturman et al. 1986) or lactation only (Crnic \& Chase, 1978; Grimble, 1981) significantly lowered milk protein concentration, while protein restriction during established lactation reduced only the milk's whey-protein concentration (Grigor et al. 1985, 1987, 1989). The influence which severe protein undernutrition has on the temporal patterns of milk composition throughout lactation remains to be elucidated.

We have previously reported (Pine et al. $1994 a, c$ ) that reductions in the protein:energy ratio of diets offered to lactating rats result in a significant suppression of food intake and impaired milk production, even though such females attempt to buffer this dietary protein inadequacy by mobilizing their endogenous reserves of protein. Although this supply of endogenous protein cannot sustain milk production at the level of similar females offered adequate dietary protein, the extent of reserve repletion at parturition can have a significant impact on lactational performance. It is not known whether such protein restriction and maternal protein catabolism has any effect on milk composition. However, changes in the weight gain of a standardized litter during mid lactation, a qualitative index of milk yield, suggested that maternal protein reserves had become depleted and constrained milk production by reducing the amino acid supply to the mammary gland (Pine et al. 1994a, c). Whether this reduced litter-weight gain was the result of a diminished milk yield alone or whether there were associated changes in milk quality is uncertain. Since the concentrations of fat and protein in milk are determined largely by their rate of synthesis relative to that of lactose, and thus the flow of water into the Golgi body (Davies et al. 1983), milk protein production could have been impaired through the reduced protein supply and thus altered milk composition.

Using the weight gain of rat pups during lactation as an index of milk production has limited value because no consideration can be given to possible variations in milk composition. Milk yields from lactating dams can be estimated using a variety of other techniques, including the increase in mammary weight following the separation of dams and pups (Grigor \& Thompson, 1987) or the dilution of tritiated water in rat pups (Knight et al. 1984). Such invasive and destructive techniques are technically laborious and therefore not practicable in many studies of lactation. However, the problem of accurately estimating milk yield during lactation in the rat has been aided by the development of techniques that estimate milk yield from the weight gain of rat pups while accounting also for their maintenance requirements (Grigor et al. 1987; Sampson \& Jansen, 1984a). Although these techniques were developed using well-nourished dams during the first 2 weeks of lactation, they are thought to be equally applicable to undernourished dams provided the dietary restriction does not alter milk composition. In order to evaluate the degree of inaccuracy which might be associated with the assumption of a constant milk composition in lactational studies with rodents, the present study has explored the impact of dietary protein restriction on milk composition.

The objective of the current study was to investigate the effect of severe protein restriction following parturition on the changes in rat milk composition during lactation. 


\section{MATERIALS AND METHODS}

\section{Experimental protocol}

Thirty-two multiparous female Sprague-Dawley rats (Harlan and Olac Ltd., Shaws Farm, Bicester, Oxon) weighing on average 306.7 (SE 4.9) g were caged individually in a room regulated at $22^{\circ}$, with relative humidity from $40-60 \%$ and a $12 \mathrm{~h}$ light-dark cycle, with the light period from 11.00-23.00 hours. Females were placed individually in a wire-bottomed cage with a proven male breeder for mating. The morning on which mating was confirmed, through the presence of vaginal plugs, was designated day 1 of gestation and the females were returned to solid-bottomed plastic cages for the remainder of the experiment.

From day 1 of gestation all females were offered a high-protein diet $(\mathrm{H}, 215 \mathrm{~g}$ crude protein $(\mathrm{N} \times 6.25 ; \mathrm{CP}) / \mathrm{kg}$ dry matter (DM); Table 1) ad lib. until parturition. The day on which parturition occurred was designated day 1 of lactation.

Subsequently, from day 1 of lactation half the females continued to receive diet $\mathrm{H}$ ad lib. whilst the remainder were offered a low-protein diet, L $(90 \mathrm{~g} \mathrm{CP} / \mathrm{kg} \mathrm{DM}$; Table 1$)$ ad lib. During lactation, groups of females $(n 4)$ from both dietary treatments were used to provide milk samples on days 2, 4, 8 and 12. Females were first separated from their litters for $2 \mathrm{~h}$ at the start of the light cycle, with dams being allowed access to the appropriate diet during the separation period, after which time they were lightly anaesthetized (diethyl ether) and injected subcutaneously with 5 IU oxytocin (Sigma Chemical Co., Poole, Dorset) in saline. Milk samples $(0.5-0.75 \mathrm{ml})$ were then obtained by gently stripping the left thoracic and abdominal teats and stored at $-20^{\circ}$ before analysis. Individual females provided only one milk sample, and following milking the females were used for the analysis of tissue protein metabolism (which will be reported separately, Pine et al. 1994b) and culled. The mammary gland from the side that had not been milked was also weighed and analysed for protein (Lowry et al. 1951).

The diets used in this study were formulated to provide approximately $21 \mathrm{MJ}$ gross energy (GE)/kg DM with a constant carbohydrate: fat ratio of 2:3:1 (Table 1). In order to maximize the lactational stress imposed, all litters were standardized to twelve pups on day 1 of lactation, using pups reared under identical gestational conditions, and litter weights were recorded daily throughout lactation. Dam body weights and food intakes were recorded daily throughout the experiment. All females were given free access to drinking water.

Litters from all females were analysed for their protein and fat contents as previously described (Pine et al. 1994c).

\section{Analysis of milk composition}

All milk samples were analysed individually for their lactose, total protein, total lipid and mineral contents. Milk lactose concentration was estimated enzymically using a lactose test kit (Boehringer Mannheim, Lewes, Sussex) after the milk sample had been deproteinized using trichloroacetic acid. Total milk protein was measured through reaction with the Coomassie protein assay reagent (Pierce Chemical Co., Oud Beijerland, The Netherlands) using casein as a standard, while total milk lipid was estimated gravimetrically (Bligh \& Dyer, 1959) following a three-times extraction with chloroform-methanol $(2: 1 ; \mathrm{v} / \mathrm{v})$. The milk samples were also assayed for $\mathrm{Na}, \mathrm{K}, \mathrm{Ca}, \mathrm{P}$ and $\mathrm{Mg}$ using a simultaneous inductively coupled plasma atomic emission spectrometer (ICAP 61E; Thermo Jarrell Ash Corporation, Franklin, MA, USA). 
Table 1. Composition of the high-and low-protein diets $(\mathrm{g} / \mathrm{kg}$ dry matter $(D M))$

\begin{tabular}{lrr}
\hline \hline & High & Low \\
\hline Ingredients & & \\
Casein* & 215 & 90 \\
Starch-sucrose $†$ & 443 & 530 \\
Maize oil & 192 & 230 \\
Vitamin mix & 50 & 50 \\
Mineral mix & 50 & 50 \\
Maize starch & 43 & 43 \\
Choline chloride & 7 & 7 \\
Lecithin§ (g/kg fresh wt) & 2 & 2 \\
Butylated hydroxytoluene $\|(\mathrm{g} / \mathrm{kg}$ fresh wt) & 0.01 & 0.01 \\
Analysis & & \\
Protein (g CP/kg DM) & 214 & 94 \\
GE (MJ/kg DM) & 21.6 & 21.4 \\
\hline \hline
\end{tabular}

$\mathrm{CP}$, crude protein $(\mathrm{N} \times 6-25)$; $\mathrm{GE}$, gross energy.

* Supplemented with DL-methionine $(99: 1 \mathrm{w} / \mathrm{w})$.

$\dagger$ Starch and sucrose mixture, $2: 1 \mathrm{w} / \mathrm{w}$.

$\ddagger$ Vitamin and mineral mixtures were formulated to meet National Research Council (1978) requirements.

$\S$ Emulsifier.

|| Antioxidant.

\section{Statistical analysis}

Dietary effects on maternal weight loss, feed intake during lactation and litter-weight gains were assessed by analysis of variance. The effects of diet and stage of lactation on milk composition were analysed using two-way analysis of variance, and by calculations of least significant differences; $t$ tests were used to compare means of samples between individual days and diet.

\section{RESULTS}

Maternal body-weight changes, gestational feed intakes, litter size (pups/litter) and mean pup birth weight following parturition of females subsequently offered diets $H$ and $L$ during lactation are shown in Table 2. Females offered diets $\mathrm{H}$ or $\mathrm{L}$ during lactation had achieved similar levels of maternal weight gain, feed intake and litter size during gestation.

Effects of lactational dietary treatment on maternal body-weight changes, feed intakes, litter-weight gains and mammary gland weight and protein content during lactation The feed intakes, body-weight changes and litter-weight gains of dams offered diet $\mathbf{H}$ or $\mathbf{L}$ during lactation and slaughtered on day 12 are shown in Table 3 . The changes in maternal body weight, feed intakes and lactational performance were all significantly affected by the lactational dietary treatments. The feeding of diet $L$ during lactation resulted in a considerably greater weight loss by group $\mathrm{L}(P<0 \cdot 001)$, which was also greater than their weight gain during gestation (Table 2).

The mean daily feed intake ( $\mathrm{g} \mathrm{DM} / \mathrm{d})$ and litter-weight gain $(\mathrm{g} / \mathrm{d})$ of all females offered diets $\mathbf{H}$ and $\mathbf{L}$ during lactation are shown in Figs. 1 and 2. Except for day 1, both feed intake and litter-weight gain were greater throughout lactation for females offered diet $\mathrm{H}(P<$ 0.05 ) and reached a maximum of 43.0 (SE 4.1$) \mathrm{g} \mathrm{DM} / \mathrm{d}$ and 31.2 (SE 1.5$) \mathrm{g} / \mathrm{d}$ respectively on day 11. Consequently, this resulted in a greater total feed intake (g DM) and litter-weight gain $(\mathrm{g})$ during lactation for females offered diet $\mathrm{H}(P<0.01$, Table 3$)$. 
Table 2. Maternal body-weight gain and feed intake during gestation, and pup birth weight of rats subsequently offered high $(H)$ - or low $(L)$-protein diets during lactation*

(Mean values with their standard errors for sixteen rats)

\begin{tabular}{|c|c|c|c|c|}
\hline & \multicolumn{4}{|c|}{ Lactation diet } \\
\hline & \multicolumn{2}{|c|}{ H (n 16) } & \multicolumn{2}{|c|}{$L(n 16)$} \\
\hline & Mean & SE & Mean & SE \\
\hline Dam wt, day 1 gestation (g) & 310 & $5 \cdot 4$ & 298 & $5 \cdot 1$ \\
\hline Dam wt gain $\dagger(\mathrm{g})$ & $48 \cdot 4$ & $4 \cdot 0$ & $56 \cdot 0$ & $3 \cdot 9$ \\
\hline Feed intake (g DM) & 351 & $9 \cdot 4$ & 369 & $9 \cdot 0$ \\
\hline Litter size (pups/litter) & $9 \cdot 5$ & $1 \cdot 0$ & $11 \cdot 0$ & $1 \cdot 0$ \\
\hline Mean pup birth wt (g) & $6 \cdot 4$ & $0 \cdot 1$ & 6.5 & $0 \cdot 1$ \\
\hline
\end{tabular}

DM, dry matter.

* For details of diets and procedures, see Table 1 and p. 817.

$\uparrow$ Dam weight gain over days 1-22, measured after parturition.

Table 3. Maternal weight loss, feed intake, litter-weight gain, mammary gland weight and protein content in rats offered either a high $(H)$ - or a low $(L)$-protein diet during lactation $\dagger$

(Mean values with their standard errors for four rats)

\begin{tabular}{|c|c|c|c|c|}
\hline & \multicolumn{4}{|c|}{ Lactation diet } \\
\hline & \multicolumn{2}{|c|}{$\mathrm{H}$} & \multicolumn{2}{|c|}{$\mathbf{L}$} \\
\hline & Mean & SE & Mean & $\mathbf{S E}$ \\
\hline Dam wt loss $(\mathrm{g} / 12 \mathrm{~d}) \ddagger$ & $12 \cdot 5$ & 6.8 & $92 \cdot 9 * * *$ & $9 \cdot 0$ \\
\hline Dam feed intake (g DM/12 d) + & 342 & 17.8 & $187^{* *}$ & $15 \cdot 6$ \\
\hline Litter-weight gain $(\mathrm{g} / 12 \mathrm{~d}) \ddagger$ & 246 & 14.7 & $87^{* *}$ & $4 \cdot 7$ \\
\hline \multicolumn{5}{|l|}{ Mammary weight $\S(\mathrm{g})$} \\
\hline Day 2 & $9 \cdot 0$ & 0.87 & $10 \cdot 7$ & $1 \cdot 10$ \\
\hline 4 & $10 \cdot 2$ & 1.54 & 8.6 & $1 \cdot 36$ \\
\hline 8 & $12 \cdot 3$ & 0.96 & $8 \cdot 3 *$ & 0.58 \\
\hline 12 & $13 \cdot 6$ & $1 \cdot 27$ & $7 \cdot 4^{*}$ & $0 \cdot 27$ \\
\hline \multicolumn{5}{|l|}{ Mammary protein (g) } \\
\hline Day 2 & 0.89 & 0.08 & $1 \cdot 12$ & $0 \cdot 16$ \\
\hline 4 & 1.08 & 0.19 & 0.92 & 0.15 \\
\hline 8 & 1.33 & 0.13 & $0.75^{*}$ & 0.06 \\
\hline 12 & 1.39 & 0.06 & $0.69^{*}$ & 0.03 \\
\hline
\end{tabular}

DM, dry matter.

Mean values were significantly different from those of the high-protein group: ${ }^{*} P<0.05,{ }^{* *} P<0 \cdot 01,{ }^{* *} P<$ 0.001 .

$\dagger$ For details of diets and procedures, see Table 1 and p. 817 .

Means of dams slaughtered on day 12 .

$\S$ Right hand abdominal and thoracic glands.

The feeding of diet $\mathrm{H}$ during lactation promoted a significant increase in mammary gland weight and protein concentration, whilst the low-protein diet resulted in significant mammary regression (Table 3). Consequently, on days 8 and 12 of lactation both mammary gland weight and protein concentration were higher in dams offered diet $\mathbf{H}$ $(P<0.05)$. 


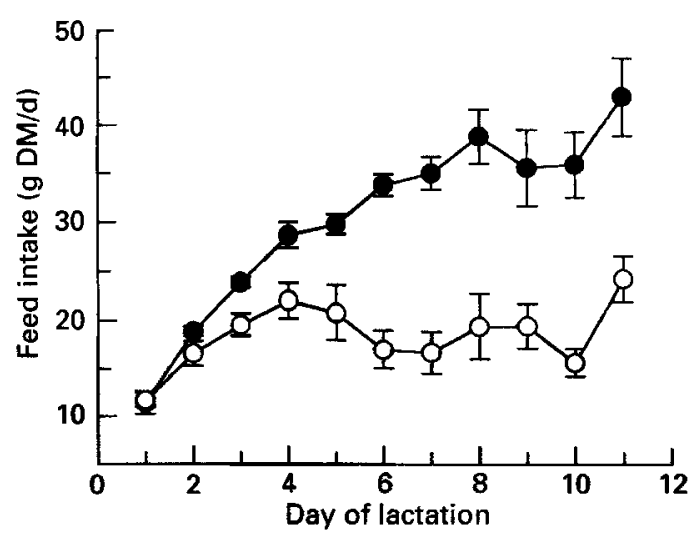

Fig. 1. Daily feed intake (g dry matter (DM)) of female rats offered either a high (O)- or a low (O)-protein diet during lactation. Values are means for all rats offered each diet at each stage of lactation, with their standard errors indicated by vertical bars. For details of diets, see Table 1.

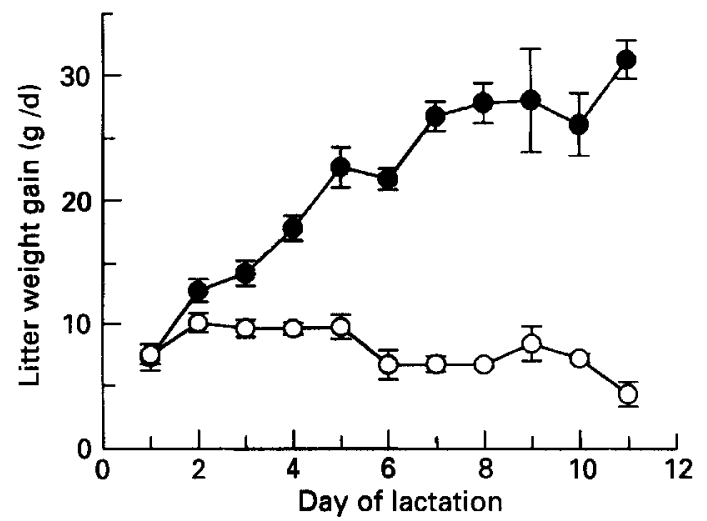

Fig. 2. Daily litter-weight gain (g) for female rats offered either a high (O)- or a low (O)-protein diet during lactation. Values are means for all rats offered each diet at each stage of lactation, with their standard errors indicated by vertical bars. For details of diets, see Table 1.

The changes in litter protein and fat contents during lactation on both dietary treatments are shown in Fig. 3. Both the litter protein and fat contents of group $\mathrm{L}$ were lower $(P<$ $0.01)$ than those of females offered diet $\mathrm{H}$ during lactation, with this difference becoming significant after day 4 .

\section{Effect of lactational dietary treatments and stage of lactation on the macronutrient composition of rat milk}

Lactose. Milk lactose concentration was significantly affected by both the dietary protein concentration and stage of lactation (Fig. 4). Milk lactose of group $\mathrm{H}$ increased significantly with stage of lactation $\left(r^{2} 0 \cdot 85, P<0.001\right)$ whilst for group L it did not. By day 8 , milk lactose concentration was significantly greater for group $\mathrm{H}$ than group $\mathrm{L}(P<0.05)$ and remained so on day 12 .

Total protein. The effects of lactational dietary treatment and stage of lactation on milk protein concentration are shown in Fig. 5. During the period of lactation studied the milk protein concentration of group $\mathbf{H}$ did not change significantly and averaged $90 \cdot 7$ (SE 1.9) $\mathrm{mg} / \mathrm{g}$. 


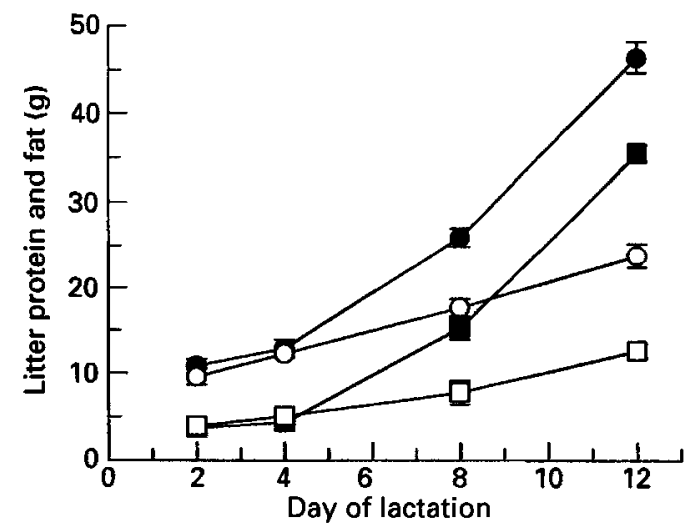

Fig. 3. Changes in the litter content $(g)$ of protein $(O, O)$ and fat $(\square, \square)$ for female rats offered either a high (closed symbols)- or a low (open symbols)-protein diet during lactation. Values are means of four standard litters of twelve pups each, killed on either day 2, 4, 8 or 12 of lactation, with their standard errors represented by vertical bars. For details of diets and procedures, see Table 1 and p. 817.

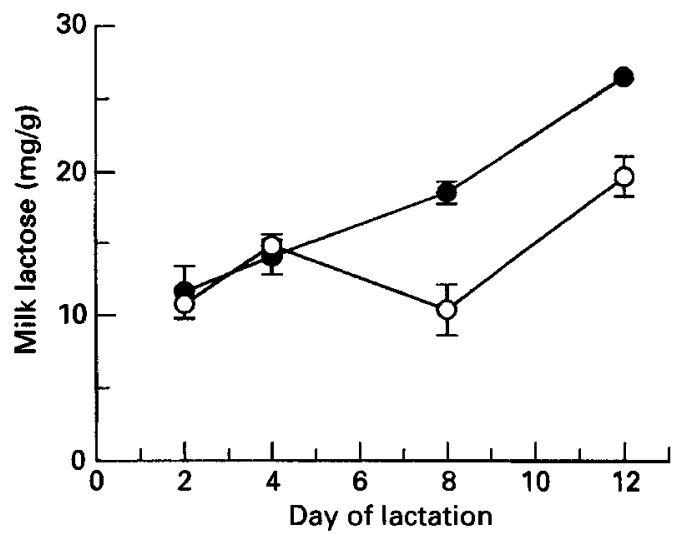

Fig. 4. Changes in the milk lactose concentration $(\mathrm{mg} / \mathrm{g})$ of female rats offered either a high (O)- or a low (O)protein diet during lactation. Four separate females from each dietary treatment were used to provide milk samples on either day $2,4,8$ or 12 of lactation. Values are means with their standard errors represented by vertical bars. For details of diets and procedures, see Table 1 and p. 817.

The feeding of diet $\mathrm{L}$ during lactation resulted in the milk protein concentrations on day $2(79.8$ (SE 2.6$) \mathrm{mg} / \mathrm{g})$ and day $4(76.4(\mathrm{SE} 0.7) \mathrm{mg} / \mathrm{g})$ being lower $(P<0.05)$ than those of group $H(90.5(\mathrm{SE} 4.1)$ and $89.4(\mathrm{SE} 4.7) \mathrm{mg} / \mathrm{g})$. However, by day 8 the milk protein concentration of group $\mathrm{L}$ had increased $(P<0.05)$ to $98.3(\mathrm{sE} 3.4) \mathrm{mg} / \mathrm{g}$, which did not differ from that of group $\mathrm{H}(91 \cdot 3$ (SE $4 \cdot 0) \mathrm{mg} / \mathrm{g}$ ). Milk protein concentration of group $\mathrm{L}$ was not maintained at this level and by day 12 had fallen $(P<0.05)$ to 81.2 (SE 3.8$) \mathrm{mg} / \mathrm{g}$, and was again lower than that of group $\mathrm{H}(P<0.05)$.

Total lipid. The effects of lactational dietary treatment and stage of lactation on milk lipid concentration are shown in Fig. 6. For group $H$, total milk lipid concentration averaged 166.8 (SE 5.8 ) $\mathrm{mg} / \mathrm{g}$ and, apart from the day 4 concentration being lower than that on day $8(P<0.05)$, was not significantly changed during lactation. The feeding of diet $\mathrm{L}$ during lactation increased $(P<0.01)$ the milk fat concentration to an average of $205 \cdot 5$ (SE $13 \cdot 5) \mathrm{mg} / \mathrm{g}$. 


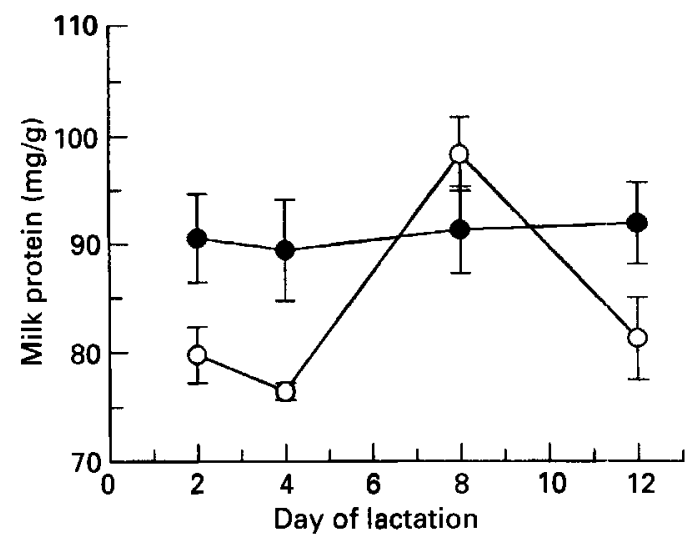

Fig. 5. Changes in the milk protein concentration $(\mathrm{mg} / \mathrm{g})$ of female rats offered either a high $(O)$ - or a low $(O)$ protein diet during lactation. Four separate females from each dietary treatment were used to provide milk samples on either day $2,4,8$ or 12 of lactation. Values are means with their standard errors represented by vertical bars. For details of diets and procedures, see Table 1 and p. 817.

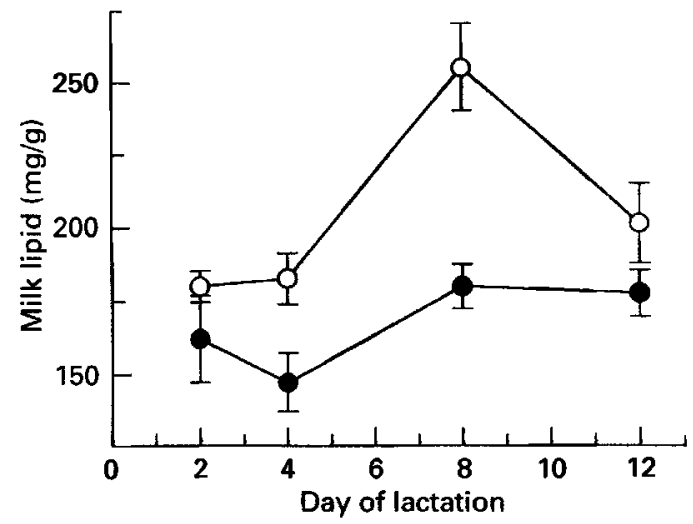

Fig. 6. Changes in the milk lipid concentration $(\mathrm{mg} / \mathrm{g})$ of female rats offered either a high (O)- or a low $(O)$ protein diet during lactation. Four separate females from each dietary treatment were used to provide milk samples on either day $2,4,8$ or 12 of lactation. Values are means with their standard errors represented by vertical bars. For details of diets and procedures, see Table 1 and p. 817.

By day 4 of lactation the milk lipid concentration of group L (182.8 (SE 8.5) $\mathrm{mg} / \mathrm{g}$ ) was higher $(P<0.05)$ than that of group H $(147 \cdot 3(\mathrm{SE} 10.3) \mathrm{mg} / \mathrm{g})$. Group L milk lipid had increased further $(P<0.05)$ by day 8 to $255.4($ SE 14.8$) \mathrm{mg} / \mathrm{g}$ and was again higher than that of group $\mathrm{H}(P<0.001)$. However, in a similar fashion to milk protein, the milk lipid concentration of group $\mathrm{L}$ subsequently declined $(P<0.05)$ and by day 12 there was no significant difference in milk lipid concentration between groups $\mathrm{H}(177 \cdot 7$ (SE 7.9$) \mathrm{mg} / \mathrm{g})$ and $\mathrm{L}(201.3$ (SE 13.5) $\mathrm{mg} / \mathrm{g}$ ).

The effect of lactational dietary treatments and stage of lactation on the sodium, potassium, calcium, phosphorus and magnesium contents of rat milk

The procedure used for measuring the mineral content of the rat milk samples provided information on the total quantity of $\mathrm{Na}, \mathrm{K}, \mathrm{Ca}, \mathrm{P}$ and $\mathrm{Mg}$. The assay was unable to partition the ions between their diffusible and non-diffusible pools. The results reported can therefore only represent the total ion content of rat milk. 


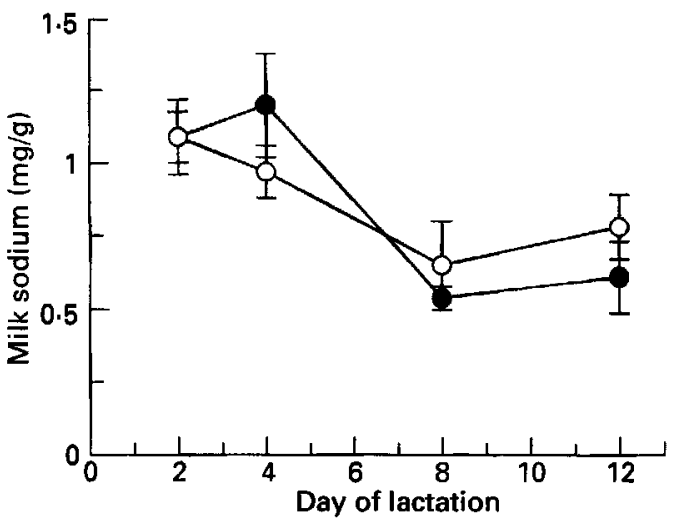

Fig. 7. Changes in the milk sodium concentration $(\mathrm{mg} / \mathrm{g})$ of female rats offered either a high (O)- or a low $(\mathrm{O})$ protein diet during lactation. Four separate females from each dietary treatment were used to provide milk samples on either day $2,4,8$ or 12 of lactation. Values are means with their standard errors represented by vertical bars. For details of diets and procedures, see Table 1 and p. 817.

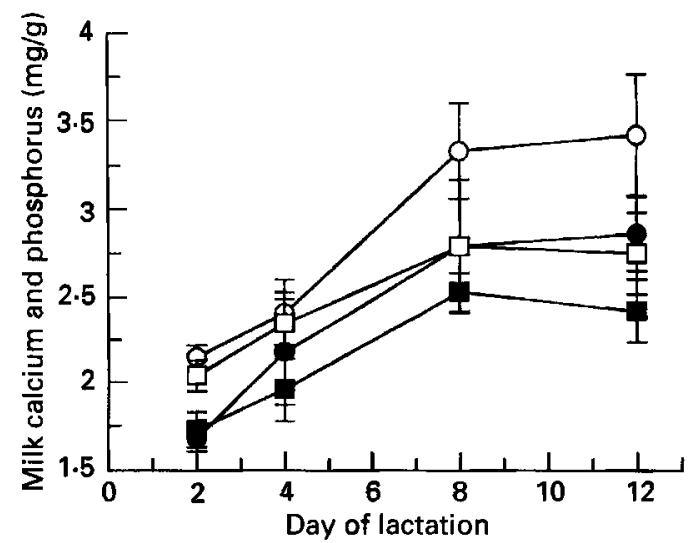

Fig. 8. Changes in the milk calcium $(0,0)$ and phosphorus $(\square, \square)$ concentrations $(\mathrm{mg} / \mathrm{g})$ of female rats offered either a high (closed symbols)- or a low (open symbols)-protein diet during lactation. Four separate females from each dietary treatment were used to provide milk samples on either day $2,4,8$ or 12 of lactation. Values are means with their standard errors represented by vertical bars. For details of diets and procedures, see Table 1 and p. 817 .

The effects of the lactational dietary treatments and stage of lactation on milk $\mathrm{Na}$ concentration are shown in Fig. 7. Although the level of dietary protein had no significant effect, milk Na concentration declined during lactation in both dietary groups $(P<0.01)$.

Both milk $\mathrm{Ca}$ and $\mathrm{P}$ contents were significantly influenced by dietary protein concentration and stage of lactation (Fig. 8). Although on each day studied milk $\mathrm{Ca}$ contents were not significantly different, throughout lactation the low-protein diet increased the milk Ca concentration of group $\mathrm{L}(2 \cdot 77$ (SE 0.17$) \mathrm{mg} / \mathrm{g})$ when compared with group H $(2.36$ (SE 0.15$) \mathrm{mg} / \mathrm{g} ; P<0.05)$. Likewise, milk $P$ concentration was increased in group L $(2.48$ (SE 0.12$) \mathrm{mg} / \mathrm{g})$ when compared with group $\mathrm{H}(2.11$ (SE 0.11$) \mathrm{mg} / \mathrm{g} ; P<$ $0.05)$. Milk Ca concentration also increased through lactation $(P<0.01)$ for groups $\mathrm{H}$ and $\mathrm{L}$ to values on day 12 of 2.86 (SE 0.21 ) and 3.42 (SE 0.34$) \mathrm{mg} / \mathrm{g}$ respectively. The increase in milk $\mathrm{P}$ content during lactation $(P<0.01)$ reached a peak of 2.53 (SE 0.11$)$ and 2.79 (SE 0.28$) \mathrm{mg} / \mathrm{g}$ on day 8 for groups $\mathrm{H}$ and $\mathrm{L}$ respectively. 


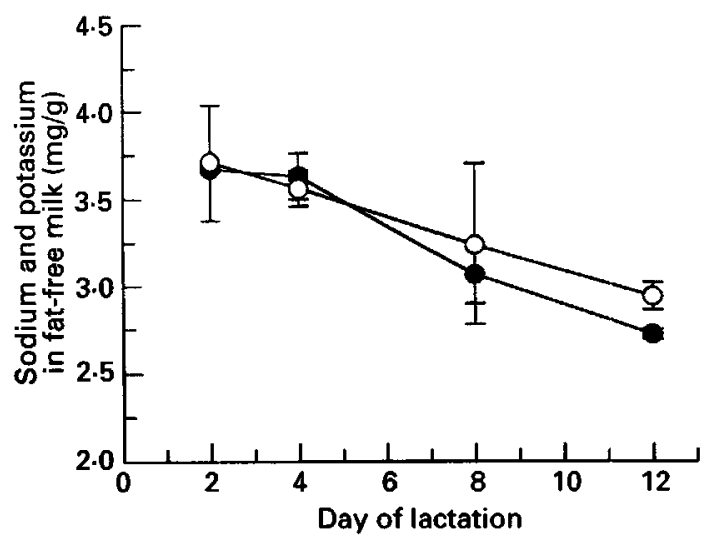

Fig. 9. Changes in the combined sodium and potassium concentrations of fat-free milk $(\mathrm{mg} / \mathrm{g})$ of female rats offered either a high (O)- or a low $(O)$-protein diet during lactation. Four separate females from each dietary treatment were used to provide milk samples on either day $2,4,8$ or 12 of lactation. Values are means with their standard errors represented by vertical bars. For details of diets and procedures, see Table 1 and p. 817 .

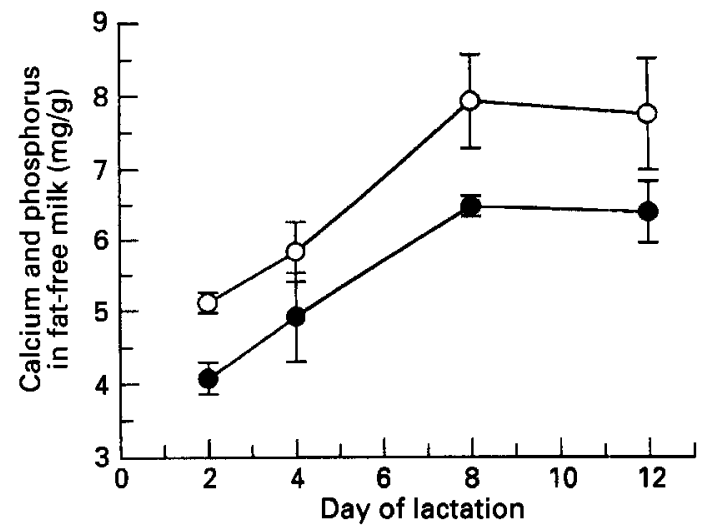

Fig. 10. Changes in the combined calcium and phosphorus concentrations of fat-free milk (mg/g) of female rats offered either a high (O)- or a low (O)-protein diet during lactation. Four separate females from each dietary treatment were used to provide milk samples on either day $2,4,8$ or 12 of lactation. Values are means with their standard errors represented by vertical bars. For details of diets and procedures, see Table 1 and p. 817 .

Dietary treatment or stage of lactation had no significant effect on the milk concentration of $\mathrm{K}$ or $\mathrm{Mg}$. $\mathrm{K}$ contents for groups $\mathrm{H}$ and $\mathrm{L}$ averaged 1.88 (SE 0.07) and 1.81 (SE 0.01) mg/g respectively, while milk $\mathrm{Mg}$ levels were 0.21 (SE 0.01 ) and 0.22 (SE 0.10 ) $\mathrm{mg} / \mathrm{g}$ respectively.

Since milk salts exist primarily as either ions in solution, bound to protein or associated with casein micelles, they are concentrated in the milk's aqueous phase. Variations in the milk lipid concentration will therefore dilute the ion concentration in whole milk and possibly mask any changes in ion concentration associated with the aqueous phase. It is therefore worth considering the possible effects of dietary protein concentration and stage of lactation on the ion concentration of fat-free milk (FFM).

The effects of dietary protein concentration and stage of lactation on the combined $\mathrm{Na}$ and $\mathrm{K}$ contents $(\mathrm{NaK})$ of FFM are shown in Fig. 9. The $\mathrm{NaK}$ concentration decreased with stage of lactation in groups $\mathrm{H}$ and $\mathrm{L}(P<0.05)$ to values on day 12 of 2.72 (SE 0.03$)$ and 2.94 (SE 0.08) $\mathrm{mg} / \mathrm{g}$ FFM respectively. Dietary protein concentration had no significant 
effect on the NaK concentration of FFM and the decline during lactation was the result of a fall in milk $\mathrm{Na}$ concentration (Fig. 7).

The combined $\mathrm{Ca}$ and $\mathrm{P}$ concentration (CaP) of FFM was significantly affected by the lactation diet and stage of lactation, increasing through lactation in groups $\mathrm{H}$ and $\mathrm{L}$ to values on day 12 of 6.39 (SE 0.44$)$ and 7.74 (SE 0.76$) \mathrm{mg} / \mathrm{g}$ FFM respectively $(P<0.05$; Fig. $10)$. During lactation CaP concentration of FFM was increased by the low-protein diet $(P<0.05,6.65$ (SE 0.4) v. 5.44 (0.33) $\mathrm{mg} / \mathrm{g} \mathrm{FFM})$. This significant difference was also evident on day 8 of lactation $(7.92$ (SE 0.64$)$ v. 6.49 (SE $0 \cdot 15) \mathrm{mg} / \mathrm{g}$ FFM).

\section{DISCUSSION}

If the effects of variations in nutrient supply on rat milk composition and lactational performance are to be investigated, it is essential that the milk sample obtained reflects that received by the sucking young. Since prolonged milk stasis within the gland $(>4 \mathrm{~h})$ significantly reduces the milk fat concentration in rats (Grigor et al. 1986), milk samples were obtained in this study after only a $2 \mathrm{~h}$ separation of dam and litter. It was also intended that sampling during the early light phase would limit the impact of the diurnal variations in mammary lipogenesis and lactose synthesis (Williamson et al. 1984). All dams were milked only once because of the effect of serial milking on the milk micronutrient concentration (Keen et al. 1980). The milk Na:K ratio ranged from $1: 1 \cdot 8-1: 3 \cdot 7$, close to the $1: 3$ reported for milk from many species and for intracellular fluid (Peaker, 1977). Thus the oxytocin treatment was taken to have had little impact on milk composition (Linzell et al. 1975).

The results of the current study are in agreement with those of earlier experiments from this laboratory and confirm that severe reductions in the protein:energy ratio of diets offered to lactating rats can drastically impair feed intake and therefore lactational performance (Pine et al. 1994a,c). Protein-restricted females can supplement this dietary supply by mobilizing their endogenous reserves of protein (Naismith et al. 1982; Friggens, 1990) and in females offered a diet of similar protein:energy ratio as used in the present study (L), such protein catabolism can supply up to $1.0 \mathrm{~g} / \mathrm{d}$ of endogenous protein, although at such a rate reserves are thought to be depleted within 6-9 d (Pine et al. 1994c).

The feeding of diet $\mathbf{H}$ promoted an increase in mammary size. This is likely to have been allied to an increase in mammary metabolism, particularly lipogenesis (Williamson, 1980) and protein synthesis (Jansen \& Hunsaker 1986; Pine et al. 1994 b), associated with milk production. By contrast, this and earlier studies have shown that protein restriction (quantity and/or quality) during lactation results in a reduction of mammary mass and cellularity (Turner, 1973; Sampson \& Jansen 1984b).

The macronutrient concentration of milk from dams offered diet $\mathbf{H}$ during lactation agreed well with that reported in earlier studies (Luckey et al. 1954; Chalk \& Bailey, 1979; Keen et al. 1981; Grigor et al. 1985, 1987, 1989; Nicholas \& Hartmann, 1991).

The feeding of the low-protein-high-energy diet (L) increased the milk fat concentration during lactation compared with diet $\mathrm{H}(205.5$ (SE 13.5) v. 166.8 (SE 5.8) $\mathrm{mg} / \mathrm{g}$ ), with the fat concentrations also being significantly different on days 4 and 8 . An increase in milk fat concentration has been previously reported for rats protein-restricted throughout lactation (Mueller \& Cox, 1946; Crnic \& Chase, 1978; Sturman et al. 1986), while protein restriction during established lactation (20 v 10\% casein; Grigor et al. 1985, 1989; Grigor \& Thompson, 1987) resulted in milk fat concentrations on day 14 that were comparable with those on day 12 in the present study $(210 v .181 \mathrm{mg} / \mathrm{g})$.

This increase in milk fat concentration by females under severe dietary protein restriction during lactation (Fig. 6) may simply result from a reduction in milk volume whilst milk fat synthesis continues unaltered. Alternatively, it may be an attempt by such females to 
dispose of surplus energy-yielding nutrients and therefore relieve the metabolic embarrassment they encounter as a result of the imbalanced supply of protein and energyyielding nutrients that are derived from dietary and endogenous sources. However, this ability may be limited because of inhibited mammary gland lipogenesis that could be promoted by the substantial supply of dietary and endogenous lipid (Grigor \& Warren, 1980). The energy supply received by the suckling young may therefore be maintained during periods of impaired milk production by an increase in milk fat concentration and although the rate of live-weight gain differs markedly between litters suckled by dams on each diet, the composition of the gain is similar. Simple calculations suggest that the rates of litter-protein gain ( 5.13 and $1.54 \mathrm{~g} / \mathrm{d}$ between days 8 and 12 for litters of dams receiving diets $H$ and $L$ respectively) require a milk protein supply of $(H) 6.6$ and $(\mathrm{L}) 1.9 \mathrm{~g} / \mathrm{d}$ assuming an efficiency of milk protein used for growth of 0.8 (Radcliffe \& Webster, 1978; McDonald et al. 1981) together with a milk protein supply of $(\mathrm{H}) 0.76$ and $(\mathrm{L}) 0.41 \mathrm{~g} / \mathrm{d}$ for maintenance amino acid requirement (Emmans \& Oldham, 1988). From milk composition (Figs 4, 5 and 6) this is equivalent to a milk intake of (H) $79 \cdot 7$ and (L) $29 \cdot 3 \mathrm{~g} / \mathrm{d}$ or 564 and $232 \mathrm{~kJ} / \mathrm{d}$. Maintenance costs can be estimated to be (H) 182 and (L) $103 \mathrm{~kJ} / \mathrm{d}$ (Grigor et al. 1987) and costs of protein gain as (H) 153 and (L) $46 \mathrm{~kJ} / \mathrm{d}(29.9 \mathrm{~kJ} / \mathrm{g}$ protein gain, Pullar \& Webster, 1977) leaving (H) 229 and (L) $83 \mathrm{~kJ} / \mathrm{d}$ for deposition as fat. Assuming the cost of fat deposition to be $4.4 \mathrm{~kJ} / \mathrm{g}$ fat formed (Chudy \& Schiemann, 1969), these would be equivalent to a rate of lipid gain of $(\mathrm{H}) 5.2$ and (L) $1.9 \mathrm{~g} / \mathrm{d}$. Measured rates of lipid gain were (H) $5 \cdot 1$ and (L) $1 \cdot 2 \mathrm{~g} / \mathrm{d}$. The discrepancy between observed and predicted rates of lipid growth for $\mathrm{H}$ are small bearing in mind the simplicity of the approach taken, but somewhat larger for $\mathrm{L}$.

For the protein-restricted females in the current study, in addition to the tendency for the milk fat concentration to be increased, the reduced supply of protein to the mammary gland also resulted in an immediate and significant fall in milk protein concentration (12-15\%), which, apart from day 8 , remained at this reduced level throughout lactation. These changes in milk protein concentration are supported by the results of earlier studies in which severe protein restriction throughout lactation lowered the protein concentration of rat milk during mid to late lactation by $27-30 \%$ (Crnic \& Chase 1978; Sturman et al. 1986), while reductions in dietary protein quality lowered milk protein concentration by $20 \%$ (Grimble, 1981). It is likely that protein restriction exerts its effect on milk protein through a simple reduction in amino acid supply, since protein and energy restriction has been shown to reduce milk production but not protein concentration (Kliewer \& Rasmussen, 1987). Despite the growing body of evidence supporting the adverse effects of protein restriction on milk composition, the authors are unaware of any other published results concerning the impact of severe protein restriction following parturition on changes in milk protein concentration throughout lactation.

One aim of the present study was to investigate whether the use of maternal protein reserves during lactation, in response to severe protein restriction, was able to influence milk composition. It would be expected that group $\mathrm{L}$ would lose $1 \mathrm{~g}$ carcass protein/d in early lactation (Pine et al. 1994c). This did not prevent a reduction in milk protein concentration. Furthermore, since the feeding of diet $\mathrm{L}$ during lactation resulted in an impaired lactational performance (milk secretion) after day 1, it might be interpreted that the lower milk protein concentration during early lactation also reflected a reduced protein secretion.

In contrast to the above changes in milk protein and fat concentrations, there was no immediate effect of severe protein restriction following parturition on the lactose concentration of rat milk in the current study but milk lactose concentration for rats receiving diet $L$ fell, in relation to group $H$, after day 4 of lactation. 
Whatever changes in mammary metabolism are involved in the dramatic fall of milk lactose concentration, it is interesting to note that this reduction occurred during a period when the rate of litter-weight gain had fallen by over $30 \%$ (Fig. 2) and during which time there would have been a substantial depletion of maternal protein reserves (Pine et al. 1994c). How a curtailed endogenous protein supply could influence mammary carbohydrate metabolism is unclear, but if the endogenous amino acids were used to any extent as gluconeogenic precursors, a reduced supply would possibly limit the activity of the lactose synthetase complex (EC 2.4.1.22).

The osmotic pressure of milk is determined primarily by the lactose and diffusible ion concentrations, particularly $\mathrm{Na}$ and $\mathrm{K}$. Under normal conditions, following changes in one constituent the osmotic pressure is maintained by compensatory changes in the others. When continued feeding of diet $\mathbf{L}$ resulted in the significant fall in lactose concentration (days 4-8) it might be expected that the $\mathrm{Na} / \mathrm{K}$ concentrations would have been adjusted to maintain the milk's osmotic pressure. However, during this period their concentrations also fell in both whole and fat-free milk. Although the other ions measured in this study, $\mathrm{Ca}$ and $\mathrm{P}$, can also contribute to the osmotic pressure, this ability is limited because most of these ions (Ca 97\%, P 78\%) are associated with the non-diffusible phase (Davies et al. 1983). Therefore, despite the fact that their concentrations were increased considerably in both whole and fat-free milk, the impact this increase could have on the osmotic pressure is determined by its partitioning between the diffusible and non-diffusible phases. Since the osmotic pressure must be maintained and because of the uncertainty regarding the partitioning of the extra $\mathrm{Ca}$ and $\mathrm{P}$ ions, it is possible that a milk constituent that contributes to the osmotic pressure and compensates for the fall in milk lactose has been ignored. Whilst the importance of the other milk components involved in the maintenance of the osmotic pressure may be increased under such conditions, such a fall in lactose production may promote a decline in milk volume (Grimble \& Mansaray, 1987) and thus increase milk fat and protein concentrations (Fig. 5 and 6).

\section{Predictability of milk yield}

Although in the present study the weight gain of a standardized litter has been used as a qualitative index of milk production (lactational performance), this cannot be accurately used to predict milk yield since no consideration is given to pup maintenance requirements or possible variations in nutrient supply that result from alterations in milk composition. Equations have been developed that estimate rat milk yield from both pup weight and pupweight gain (Sampson \& Jansen 1984a; Grigor et al. 1987). Although the authors suggest that such equations are equally applicable to milk yield estimation from severely undernourished dams, this assumes that the nutritional challenge does not compromise milk composition. Since we have reported that severe protein restriction from parturition can quickly alter milk composition, the use of these equations under such conditions must be questioned.

Using data from the present study and the equations described by Sampson \& Jansen (1984 a) and Grigor et al. (1987), females offered diet $H$ during lactation and milk-sampled on day 8 had estimated milk yields over the preceding $24 \mathrm{~h}$ (days 7-8) of 34.4 and $39.5 \mathrm{~g} / \mathrm{d}$ respectively. This slight discrepancy in estimated milk yield $(12 \%)$ is largely the result of a lower estimate of pup maintenance requirement used by Sampson \& Jansen (1984a). When these equations are applied to data from females offered diet $\mathrm{L}$ and used for milk sampling on day 4 , milk yields for the previous $24 \mathrm{~h}$ (days 3-4) were estimated to be 17.6 and $15.5 \mathrm{~g} / \mathrm{d}$ respectively and, as might be expected, were considerably lower than the 23.9 and $20.9 \mathrm{~g} / \mathrm{d}$ calculated for group $\mathrm{H}$.

Using values for milk composition from the same females it is also possible to estimate 
the milk yield needed to supply the pup maintenance and gain requirements over $24 \mathrm{~h}$. The litter protein requirement for maintenance was determined using the equation derived from Emmans \& Oldham (1988) $\left(10 \times 0.07^{-0.27} \times\right.$ body protein), a digestibility of milk protein 0.95 (Radcliffe \& Webster, 1978) and an efficiency of absorbed protein use of 0.85 (McDonald et al. 1981). Litter-protein gain on day 7 (days 7-8) was estimated by interpolation from the litter-protein mass on day $4\left(-5 \cdot 6+0.176\right.$ litter weight; $r^{2} 95.9 \%$, $P<0.05$ ) and the protein mass on day $8(25.84$ (SE 1.1) g (Fig. 3)). The protein yield required to satisfy such growth and maintenance requirements was then converted to milk volume using the measured milk protein concentration. Thus milk yield on day 7 was estimated to be $43.7 \mathrm{~g} / \mathrm{d}, 10$ and $22 \%$ higher than the calculated yields using the equations of Grigor et al. (1987) and Sampson \& Jansen (1984a) respectively.

The milk yield for group $L$ on day 3 can also be calculated using the litter protein requirements and calculations previously described for group $H$. In this calculation for group $\mathrm{L}$, litter protein on day 2 was estimated from the equation $-5 \cdot 0+0 \cdot 165$ litter weight $\left(r^{2} 90.0 \% ; P<0.05\right)$ and the litter-protein mass on day 4 of 12.19 (SE 0.50$) \mathrm{g}$. Using these calculations and assumptions, the milk volume required to supply sufficient milk protein was $30.4 \mathrm{~g} / \mathrm{d}$, which was 42 and $49 \%$ greater than yields calculated using the equations from Grigor et al. (1987) and Sampson \& Jansen (1984a) respectively. Although this required milk volume may be slightly overestimated, unlike group $\mathrm{H}$ it can be clearly seen that since milk quality, particularly milk protein, was significantly reduced by dietary protein restriction, estimations of milk yield simply from litter weight and weight gain dramatically underestimate the volume of milk required to supply sufficient nutrients to support litter maintenance and weight gain. It can therefore be concluded that although such equations are useful for the estimation of milk yield from well-nourished dams, when dietary conditions result in an altered milk composition the application of such methods is questionable.

The estimated milk yield for group $\mathrm{L}$ of $30.4 \mathrm{~g} / \mathrm{d}$ represents a litter milk protein requirement of $2.3 \mathrm{~g} / \mathrm{d}$. Although there may be some degree of overestimation in this calculated requirement, this is actually greater than these females' dietary protein intake $(1.96(\mathrm{SE} 0 \cdot 17) \mathrm{g} / \mathrm{d})$. These estimations suggest that such females require an additional supply of protein to allow lactation to proceed successfully. This additional supply of protein will be derived from maternal protein reserves and it has been previously reported that during early lactation such protein-restricted females can supply up to $1.0 \mathrm{~g} / \mathrm{d}$ of endogenous protein (Pine et al. 1994c).

In summary it can be concluded that severe dietary protein restriction during lactation not only impairs milk production through a suppression of feed intake and a limiting protein supply, it also significantly alters milk composition. Protein restriction following parturition considerably reduces milk protein concentration while increasing milk fat concentration. Milk lactose concentration is not initially affected, but continued protein restriction results in a dramatic fall in milk lactose concentration, while at the same time concentrations of fat and protein rise. The reasons behind such alterations in milk lactose concentration and thus mammary gland carbohydrate metabolism are unknown, but it is thought that the exhaustion of maternal protein reserves and therefore the supply of endogenous protein to the gland is involved. Recently-developed methods to estimate milk production by lactating rats from litter-weight gain and litter weight can be used to provide useful information on the yield of well-nourished dams. However, under conditions in which both milk volume and composition may be adjusted, their application is in doubt.

APP gratefully acknowledges receipt of an Agricultural and Food Research Council studentship. Skilled technical assistance of G. F. Allan and L. Emsley is acknowledged. 
Statistical advice from Dr G. W. Horgan, Scottish Agricultural Statistics Service, is also acknowledged.

\section{REFERENCES}

Bligh, E. G. \& Dyer, W. J (1959). A rapid method of total lipid extraction and purification. Canadian Journal of Biochemistry and Physiology 37, 911-917.

Chalk, P. A. \& Bailey, E. (1979). Changes in the yield and carbohydrate, lipid and protein content of milk during lactation in the rat. Journal of Developmental Physiology 1, 61-79.

Chudy, A. \& Schiemann, R. (1969). Utilization of dietary fat for maintenance and fat deposition in model studies with rats. In Energy Metabolism of Farm Animals, European Association for Animal Production Publication no. 12, pp. 161-168 [K. B. Blaxter, J. Kielanowski and G. Thorbek, editors]. Newcastle-upon-Tyne: Oriel Press.

Crnic, L. S. \& Chase, H. P. (1978). Models of infantile undernutrition in rats: effects on milk composition. Journal of Nutrition 108, 1755-1760.

Davies, D. T., Holt, C. \& Christie, W. W. (1983). The composition of milk. In Biochemistry of Lactation, pp. 71-117 [T. B. Mepham, editor]. Amsterdam: Elsevier Science Publishers.

Emmans, G. C. \& Oldham, J. D. (1988). Modelling of growth and nutrition in different species. In Modelling of Livestock Production Systems, pp. 13-21 [S. Korver and J. A. M. Van Arendonk, editors]. Wageningen: Kluwer Academic Publishers.

Friggens, N. C. (1990). The effects of feed composition and level on lactational performance in rats and dairy cows: a basic approach to feed description. PhD Thesis, University of Edinburgh.

Grigor, M. R., Allan, J. E., Carne, A., Carrington, J. M. \& Geursen, A. (1985). Selective decreases in lactalbumin concentration of rat milk following consumption of a low protein diet. Proceedings of the University of Otago Medical School 63, 21-22.

Grigor, M. R., Allan, J. E., Carrington, J. M., Carne, A., Geursen, A., Young, D., Thompson, M. P., Haynes, E. B. \& Coleman, R. A. (1987). Effect of dietary protein and food restriction on milk production and composition, maternal tissues and enzymes in lactating rats. Journal of Nutrition 117, 1247-1258.

Grigor, M. R., Carrington, J. M., Arthur, P. G. \& Hartman, P. E. (1989). Lack of correlation between milk glucose concentration and rates of milk production in the rat. Journal of Dairy Research 56, 37-43.

Grigor, M. R., Poczwa, Z. \& Arthur, P. C. (1986). Milk lipid synthesis and secretion during milk stasis in the rat. Journal of Nutrition 116, 1789-1797.

Grigor, M. R. \& Thompson, M. P. (1987). Diurnal regulation of milk lipid production and milk secretion in the rat: effect of dietary protein and energy restriction. Journal of Nutrition 117, 748-753.

Grigor, M. R. \& Warren, S. M. (1980) Dietary regulation of mammary lipogenesis in lactating rats. Biochemical Journal 188, 61-65.

Grimble, R. F. (1981). Effect of dietary protein concentration and quality on hormonal status, protein metabolism and milk protein concentration of rats. Annals of Nutrition and Metabolism 25, 221-227.

Grimble, R. F. \& Mansaray, Y. K. C. (1987). Effects in rats of dietary protein inadequacy on lactose production, milk volume and components of the lactose synthase complex (EC 2.4.1.22). Annals of Nutrition and Metabolism 31, 179-184.

Jansen, G. R. \& Hunsaker, H. (1986). Effect of dietary protein and energy on protein synthesis during lactation in rats. Journal of Nutrition 116, 957-968.

Keen, C. L., Lonnerdal, B., Clegg, M. \& Hurley, L. S. (1981). Developmental changes in the composition of rat milk. Trace elements, minerals, protein, carbohydrate and fat. Journal of Nutrition 111, 226-230.

Keen, C. L., Lonnerdal, B., Sloan, M. V. \& Hurley, L. S. (1980). Effects of milking procedure on rat milk composition. Physiology and Behaviour 24, 613-615.

Kliewer, R. L. \& Rasmussen, K. M. (1987). Malnutrition during the reproductive cycle: effects on galactopoietic hormones and lactational performance in the rat. American Journal of Clinical Nutrition 46, 926-935.

Knight, C. H., Docherty, A. H. \& Peaker, M. (1984). Milk yield in rats in relation to the activity and size of the mammary secretory cell population. Journal of Dairy Research 51, 29-35.

Linzell, J. L., Peaker, M. \& Taylor, J. C. (1975). The effects of prolactin and oxytocin on milk secretion and on the permeability of mammary epithelium in the rabbit. Journal of Physiology 253, 547-563.

Lowry, O. H., Rosebrough, N. J., Farr, A. L. \& Randall, R. J. (1951). Protein measurement with the Folin phenol reagent. Journal of Biological Chemistry 193, 265-275.

Luckey, T. D., Mende, T. J. \& Pleasant, S. (1954). The physical and chemical characterisation of rat milk. Journal of Nutrition 54, 345-350.

McDonald, P., Edwards, R. A. \& Greenhalgh, J. F. D. (1981). Animal Nutrition, 3rd ed. London: Longman Publishers.

Mueller, A. J. \& Cox, W. M. Jr (1946). The effect of a change in diet on the volume and composition of rat milk. Journal of Nutrition 31, 249-259.

Naismith, D. J., Richardson, D. P. \& Pritchard, A. E. (1982). The utilization of protein and energy during lactation in the rat, with particular regard to the use of fat accumulated in pregnancy. British Journal of Nutrition 48, 433-441. 
National Research Council (1978). Nutrient Requirements of Laboratory Animals, 3rd ed. Washington, DC: National Academy of Sciences.

Nicholas, K. R., Hartmann, P. E. \& McDonald, B. L. (1981). Alpha-lactalbumin and lactose concentration in rat milk during lactation. Biochemical Journal 194, 149-154.

Nicholas, K. R. \& Hartmann, P. E. (1991). Milk secretion in the rat. Progressive changes in milk composition during lactation and at weaning and the effect of diet. Comparative Biochemistry and Physiology 98A, 535-542.

Peaker, M. (1977). The aqueous phase of milk: ion and water transport. In Comparative Aspects of Lactation, pp. 113-134 [M. Peaker, editor]. New York: Academic Press.

Pine, A. P., Jessop, N. S., Allan, G. F. \& Oldham, J. D. (1994a). Maternal protein reserves and their influence on lactational performance in rats. 2. Effects of dietary protein restriction during gestation and lactation on tissue protein metabolism and $\mathrm{Na}^{+}, \mathrm{K}^{+}$-ATPase (EC 3.6.1.3) activity. British Journal of Nutrition 72, $181-197$.

Pine, A. P., Jessop, N. S., Allan, G. F. \& Oldham, J. D. (1994 b). Maternal protein reserves and their influence on lactational performance in rats. 4. Tissue protein synthesis and turnover associated with mobilization of maternal protein. British Journal of Nutrition 72, 831-844.

Pine, A. P., Jessop, N. S. \& Oldham, J. D. (1994c). Maternal protein reserves and their influence on lactational performance in rats. British Journal of Nutrition 71, 13-27.

Pullar, J. D. \& Webster, A. J. F. (1977). The energy cost of fat and protein deposition in the rat. British Journal of Nutrition 37, 355-363.

Radcliffe, J. D. \& Webster, A. J. F. (1978). Sex, body composition and regulation of food intake during growth in the Zucker rat. British Journal of Nutrition 39, 483-492.

Sampson, D. A. \& Jansen, G. R. (1984a). Measurement of milk yield in lactating rats from pup weight gain and pup weight. Journal of Pediatric Gastroenterology and Nutrition 3, 613-617.

Sampson, D. A. \& Jansen, G. R. (1984b). Protein synthesis during lactation: no circadian variation in mammary gland and liver of rats fed diets varying in protein quality and level of intake. Journal of Nutrition 114, 1470-1478.

Sturman, J. A., Devine, E., Resnick, O. \& Morgane, P. J. (1986). Maternal protein malnutrition in the rat: effect on protein and two enzymes in milk. Nutrition Research 6, 437-442.

Turner, M. R. (1973). Perinatal mortality, growth, and survival to weaning in offspring of rats reared on diets moderately deficient in protein. British Journal of Nutrition 29, 139-147.

Williamson, D. H. (1980). Integration of metabolism in tissues of the lactating rat. FEBS Letters 117, Suppl. 1, K93-K105.

Williamson, D. H., Munday, M. R. \& Jones, R. G. (1984). Biochemical basis of dietary influences on the synthesis of the macronutrients of rat milk. Federation Proceedings 43, 2443-2447. 